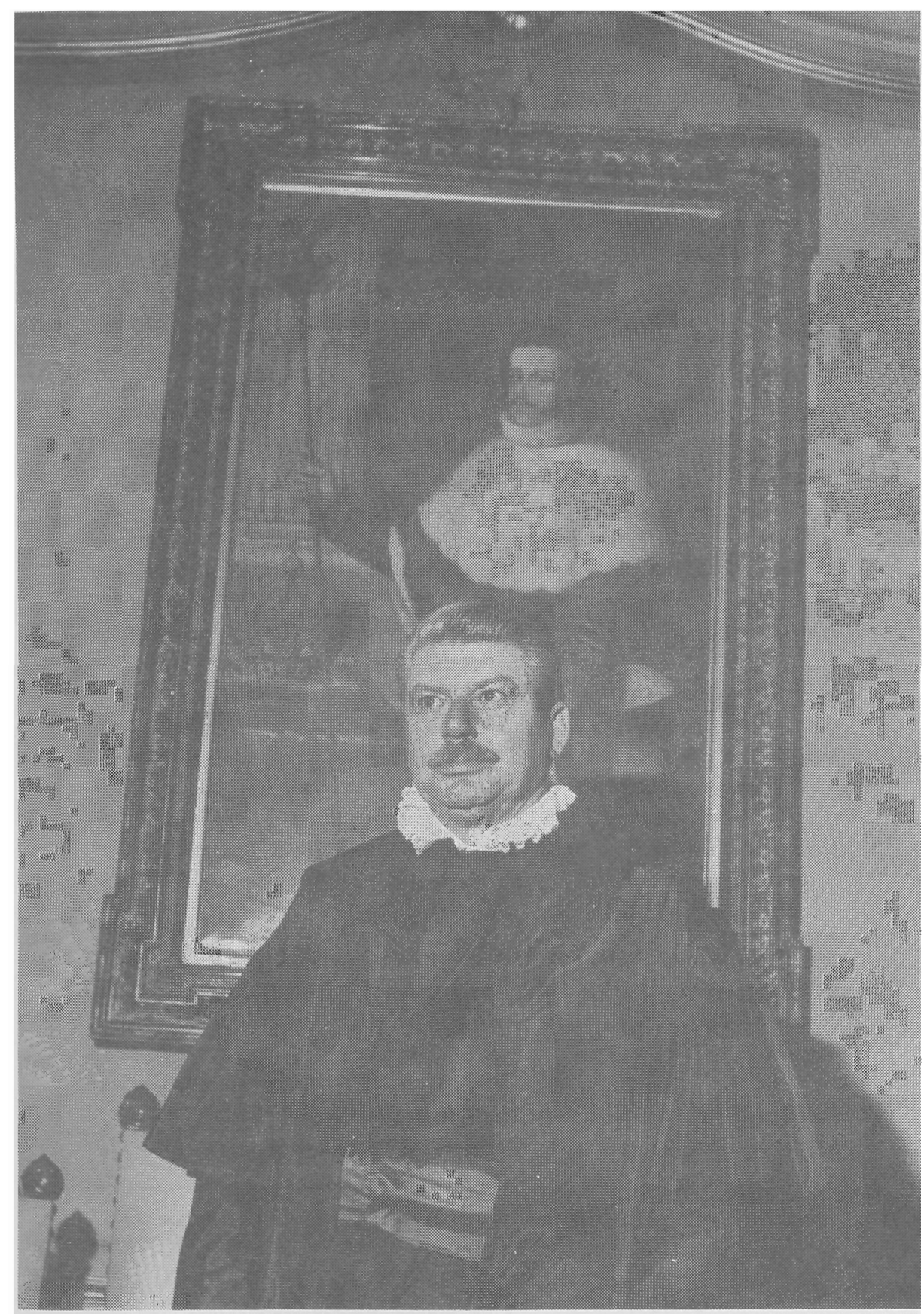

Waldírio Bulgarelli 


\title{
ATUALIDADE DO DIREITO EMPRESARIAL
}

\author{
Waldírio Bulgarelli \\ Professor Titular do Departamento de Direito Comercial \\ da Faculdade de Direito da Universidade de São Paulo
}

Resumo:

O artigo analisa preliminarmente a importância do tema no contexto brasileiro atual. O problema da excessiva regulamentação entre nós, também chamada fúria legisferante ou como dizem os franceses, decretomania. A importância da visão empresarial em razão da combalida vida econômica e şocial do país.

Trata a seguir da empresa e do empresário, faz um breve histórico do ciclo que se inicia com os marchans e os fabricans, passando ao comerciante e chegando ao empresário. As conceituações de empresa e empresário no Brasil e na Itália, teorias acerca da empresa, como instituição ou unidade de produção e as normas correlatas. Analisa a questão do enquadramento jurídico da empresa nas categorias básicas sujeito, bens, atos e fatos do Código Civil italiano e o conceito jurídico baseado na atividade e a explicação dos seus correlatos, sujeito (o empresário) e bens (o estabelecimento). A importância da adoção de um estatuto geral do empresário.

Aborda o surgimento espontâneo do Direito Comercial no seio dos mercadores e os seus primeiros tratados, da relação do Direito Comercial e os outros ramos do direito, as disputas entre eles, o problema da falta de integração e sistematização do Direito Comercial e sua evolução. Faz um breve relato sobre o Direito Comercial entre nós e o Código Comercial brasileiro. Finaliza com o quadro normativo empresarial no Brasil hoje.

Abstract:

The article analyses preliminarily the importance of the theme in the present Brazilian context. The problem of excessive regulation among us, also called legislative fury, or as the French say, decret manie. The importance of the entrepreneurial view because of the weakened social and economic life of the country.

After, it deals with the entrepreneur and the enterprise, makes a brief historical of the cycle beginning with the marchans and the

* Aula inaugural, ministrada em 05 de março de 1992, referente ao ano letivo de 1992 , período noturno, pelo novo titular de Direito Comercial. 
fabricans, going to the tradesman and getting to the entrepreneur. The concepts of enterprise and entrepreneur in Brazil and in Italy, theories about the enterprise, as an institution or production unit and correlate norms. It analyses the question of the juridical framing of the enterprise in the basic categories - subject, goods, acts and facts in the Italian Civil Code and the juridical concept based in the activity and the explanation of its correlates, subject (the entrepreneur) and goods (the establishment). The importance of the adoption of a general statute for the entrepreneur.

It goes into the spontaneous appearance of Commercial Law among the merchants and their first treaties, of the relationship between Commercial Law and the other fields of law, the disputes between them, the problem of the lack of integration and systematization in Commercial Law and its evolution. It reports briefly on the commercial law among us and the Brazilian Commercial Code. It ends with the entrepreneurial normative picture in Brazil today.

Senhor diretor, meus colegas, minhas senhoras e meus senhores, meus caros alunos.

A escolha de um professor de Direito Comercial para proferir esta aula magna parece ser demonstrativa por si mesma, do interesse que desperta e a importância que assumiu a pressão econômica exercida sobre a sociedade.

Como se trata de tema de certa forma árduo e altamente técnico, cumpre encará-lo nas suas formas mais penetrantes, e apesar do ar solene que envolve este momento, dar-lhe um tratamento o mais informal, mesmo porque ele envolve desde questões de alta transcendência, como, por exemplo, a política econômica, até as questões quotidianas, como os contratos de adesão de bens e serviços, a emissão de cheques pré-datados, os cálculos de correção monetária e tantos outros; a maioria, portanto, um suplício diuturno, envolvendo seguidamente a violação dos direitos dos cidadãos.

Trata-se de um momento peculiar, na vida jurídica pátria, em que há incontável número de leis, pouco Direito e certamente muita injustiça.

Não é de estranhar que a regulamentação legal derivada de uma orientação intervencionista estatal acendrada tenha exacerbado o número de leis e de leis com inúmeros dispositivos, visando de um lado abarcar toda a complexidade de certas operações, e de outro atentando para a proteção de certos interesses para forçar um equilibrio das forças em conflito, como ocorreu 
entre nós, com a lei sobre representantes comerciais autônomos, sobre concessionários de transportes terrestres e, ainda agora, para as relações de consumo, chamada por isso de Código de Defesa do Consumidor (Lei 8.078, de 11 de setembro de 1990). ${ }^{1}$

Não espante ninguém pois a crescente série de leis, que entre nós se chamou de fúria legisferante e na França de "decretomania".

A propósito dessa tendência, Manoel Gonçalves Ferreira Filho, já em 1968, predicava: "Crise da Lei? Crise legislativa? A referência a essas crises poderá intrigar o leigo, ou o observador desatento e superficial. Como falar em crise da Lei, em crise legislativa quando são tantas as leis e quando a cada instante novas leis se promulgam em toda parte. A multiplicação das leis é fenômeno universal e inegável. Com segurança pode-se dizer que nunca se fizeram tantas leis em tão pouco tempo. No Brasil, por exemplo, durante todo o Império, foram promulgadas cerca de 3.400 leis. Durante a primeira República, de 1891 a 1930, cerca de 2.500 leis. E de 18 de setembro de 1946 a 9 de abril de 1964, nada menos de $4.300^{\prime \prime} .2$

Ora, só em leis, veja-se que o seu número subiu para 8.100, hoje, afora os decretos, os decretos-leis, as resoluções, instruções, portarias e medidas provisórias.

Em 11 de janeiro do ano passado, o número de decretos federais atingia 100.000 , tendo começado de novo uma nova numeração a partir do Decreto no 1: sendo que nessa seqüência, três meses e meio, ou seja, de 15 de março a 30 de junho último, foram expedidas 409 normas legais; ainda nesse campo, verifica-se que no âmbito econômico, tivemos, desde os governos Figueiredo, Sarney e Collor, 20 políticas salariais, 17 políticas cambiais, 24 políticas de preço, 12 mudanças na correção monetária, 37 alterações na política tributária (Cf. Joelmir Beting, O Estado de S.Paulo, 5 jan. 1992); e ainda nos últimos seis anos, tivemos 7 planos de ajustes, 5 congelamentos de preços e 3 reformas monetárias.

1. Cf. o meu Contrato mercantil, citação a que se deve acrescer a tendência de se uniformizar os contratos de compra e venda internacionais, através da UNCITRAL.

2. Cf. Do processo legislativo, São Paulo, Saraiva, 1968, p. 11. 
Vê-se que é um momento bom para o estudo do Direito, até porque como já disse alguém: leis é que não faltam; há para todos. Deixando de lado essa boutade que tem a sua razão de ser, é inevitável assinalar que o momento é oportuno para o estudo do Direito, principalmente, ao menos por dois grupos de razões: 1 . em virtude dessa rica problemática normativa e a constante violação dos direitos dos cidadãos; 2. em virtude do progresso alcançado pela ciência jurídica nas últimas décadas deste século, em que se destacam os avanços extraordinários do estudo do Direito, como ciência e arte do justo, em que despontam novas formulações na zeetética e na dogmática, voltada esta última para a "decidibilidade", baseando-se a hermenêutica na nova retórica e na jurisprudência tópica, seguindo uma ideologia dinâmica voltada para o sccial (a razoabilidade), cabendo ao intérprete e ao aplicador da lei, a captação do que há de direito na norma, ou como querem outros, o que de eqüidade e de justiça nela se contém expressa ou implicitamente.

Evidente é que toma excepcional importância a visão empresarial, dados os abalos econômico-sociais causados pelos planos e medidas governamentais, como já assinalamos. Neste ponto, até o poder da empresa, que sempre foi prestigiado, e acabou por se tornar incômodo, ensejando as reações conhecidas, de que é exemplo máximo entre nós, o Código de Defesa do Consumidor.

Para expor essas realidades, optamos por uma língua dialógica, procurando estabelecer uma relação de dúvidas e problemas, com o nosso auditório, e como já dizia Karl Poper em relação ao conhecimento objetivo, se no espaço de uma palestra não se tem condições de convencer, ao menos podemos despertar a atenção para os problemas e a curiosidade de busca de respostas.

Como é curial, desempenha nesse processo revisionista e construtivo, papel de relevo a empresa, instituto que se tornou o epicentro da atividade econômica, com as conseqüências sociais conhecidas.

Não seria, portanto, despiciendo, perante o poder que a empresa ostenta na economia e na sociedade moderna, hoje, já comparada à Igreja e às Corporações, recordar que o seu reconhecimento jurídico foi lento e difícil e que ainda não se completou integralmente. 
A consolidação do Direito Comercial antigo até os dias de hoje, época em que se apresenta já com um verdadeiro arsenal jurídico-instrumental e seu ajuste doutrinário ao Direito como ciência, através da construção da sua Teoria Geral e de institutos complexos, já chamados de mecanismos jurídicớ, além dos tradicionais (como a compra e venda, por exemplo), ajustados todos ao novo sistema empresarial, desdobra-se na sua trajetória, em duas vertentes, que surgem com aspectos salientes a que é necessário analisar, num verdadeiro corte, não obstante o seu evolver histórico tenha sido conjugado e praticamente indecomponível na sua vivência. Trata-se, de um lado, da evolução do Direito Comercial na trilha dos progressos verificados no Direito em geral, até conciliar o seu pragmatismo com os elementos técnicos e científicos indispensáveis para a consecução dos seus objetivos, na regulação da atividade empresarial moderna; de outro, a recepçāo do regime da empresa (conceito, estrutura, função, etc.) pelo Direito, surgindo como o instituto basilar de uma nova disciplina jurídica, caracterizadora de um ramo próprio e específico do Direito, exatamente o Direito Empresarial dos nossos dias.

Ao refletir sobre o regime jurídico atual das atividades econômicas, nos dias de hoje, e não só no Brasil, como em vários países da Europa continental, como a França e a Alemanha, por exemplo, deparamo-nos com uma situação no mínimo tripartida, em que se destacam normas voltadas para as atividades econômicas civis (chamemos assim o plano obrigacional em que o Direito Civil atua), em que avulta uma disciplina jurídica das sociedades civis, dos contratos e obrigações etc.; outra disciplina voltada para os comerciantes e as relaçóes decorrentes da sua atividade, e ainda, embora um tanto imprecisamente, normas voltadas para o empresário ou à empresa ou ao estabelecimento, não ainda suficientemente sistematizadas, excluindo-se para efeito desta análise o sem-número de normas de Direito Econômico, de Direito do Trabalho, de Direito Fiscal e de Direito Administrativo.

Ora, fácil é de ver, e todos os que se dedicam ao Direito Empresarial o sabem, que essa tricotomia não se apresenta harmonicamente, ensejando por isso mesmo conflitos e choques, tanto de qualificação como de subsunção, na tarefa de interpretação e aplicação dessas normas.

Destarte as conseqüências inevitáveis são as dificuldades em considerar certas atividades, relações e contratos, como comerciais, civis ou 
empresariais, como vêm ocorrendo, por exemplo, para as questões referentes a concordatas, a falência e a renovatória de aluguel das locações comerciais. Aliás, é este um campo fértil de disputas, agravadas pela tendência verdadeiramente pendular, de muitos que desenvolvem um tipo de atividade pretenderem ser considerados como enquadrados em outras, para auferir certos benefícios das leis; tome-se, como exemplo, o de certas empresas (inclusive, os produtores rurais) que pretendem seja-lhes reconhecido o benefício da concordata, através da sua equiparação ao regime jurídico dos comerciantes; já outras empresas de caráter comercial pretendem não se enquadrar no regime dos comerciantes, para fugir à decretação da falência; e outras ainda, de naturezas diversas, inclusive estabelecimentos de ensino e cartórios de títulos, que pretendem se colocar ao abrigo da Lei de Luvas, e assim por diante. A esse propósito, em nossa obra sobre a Teoria Jurídica da Empresa, ${ }^{3}$ coletamos inúmeros exemplos desse tipo que incluem até a qualificação do barbeiro, de casa de tintas a de empresas de publicidade.

Pensa-se por isso o que, aliás, venho defendendo e que a jurisprudência aos poucos vai acatando que a adoção de uma disciplina legal da empresa superaria essas dificuldades, sobretudo da qualificação, absorvendo inúmeras atividades novas ou antigas, e ainda as atividades de serviços, o que constituiria um singular progresso.

É consabido que apesar de todas as resistências foi impossível afastar a empresa da consideração dos juristas e do Direito. Lembremo-nos, a propósito, que o espectro jurídico da empresa veio forcejando, como ainda hoje forceja, os regimes normativos, desde a sua consolidação econômica a partir da Revolução Industrial. Essa terceira pessoa, o empresário, ao lado do proprietário e do comerciante, ${ }^{4}$ acabou por se inserir na legislação positiva, ainda que no início através do Direito do Trabalho e do Direito Econômico. Historicamente, é cediço que o regime jurídico existente desde a Antigüidade, repousava na propriedade e ao lado dela nos privilégios decorrentes das categorias sociais (desde os Romanos conheciam-se os "status civitatis, libertatis et familiae"). E foi justamente para fugir a esse regime de privilégios já na Idade Média, que os

3. p. 230 e ss.

4. Cf. Remo Franceschelli, Imprese e imprenditori, Milão, Giuffrè, 1970, p. 8 e ss. 
mercadores e artesãos, tanto através das feiras e mercados, quanto do comércio marítimo e finalmente reunidos nas chamadas cidades-livres, foram criando o seu próprio ordenamento jurídico, que teve o seu máximo esplendor com o direito das corporações, tanto que acabaram reconhecidos certos privilégios, os quais teriam o seu fim com a Revolução Francesa. Entretanto, a burguesia capitalista nascente e vitoriosa, ao empolgar o poder, não deixou de reservar para si certos privilégios; como, por exemplo, a proteção que o regime do Direito Comercial de então dispensava aos comerciantes, de que é prova marcante entre outras as chamadas prerrogativas de que dispunham. Deixou-se fora desse regime o proprietário rural, para que não ficasse sujeito a certos ônus, obrigações e responsabilidades (inscrição no Registro de Comércio, contabilidade, falência), assim como os profissionais liberais, considerados como exercitando uma profissão livre. Entretanto, o conceito remanescia muito estreito, deixando fora inúmeras novas atividades sobretudo na área de serviços.

E foi este regime jurídico voltado para o comerciante que a empresa encontrou. Para ingressar nas relações privadas oriundas das atividades econômicas, entre nós, podem ser apontadas ao menos duas vias bem marcantes: 1. a da sua inserção em novas leis, como, por exemplo, na Consolidação das Leis do Trabalho; na Lei contra o Abuso do Poder Econômico, etc.; 2. no campo das relações privadas, pelo alargamento do conceito de mercancia, conforme referido pelo art. 4º do Código Comercial e pelo Regulamento 737; e doutrinariamente pela influência do Código Civil italiano (com seu regime empresarial) e as leis que sucessivamente foram sendo promulgadas na maioria dos países, com referências ou mesmo destinadas especificamente às empresas. Tanto assim é que o nosso Projeto do Código Civil (n⿳⺈ 634-B, 1975), acabou por distinguir os chamados, por Miguel Reale, cinco protagonistas, ou seja, o proprietário, o marido, o contratante, o testador e o empresário que considera como o principal e consagrando uma disciplina completa sobre o que chamou de Direito da Empresa. Conquanto não se tenha feito uma unificação total, o avanço foi significativo, oferecendo-se um conceito que não obstante de lege ferenda serve de subsídio doutrinário, assim como o seu correlato do art. 2.082, do Código Civil italiano, em que o empresário é qualificado pelo exercício profissional da atividade econômica de produção e distribuição de bens e serviços. Por outro lado, o alargamento do conceito de mercancia, vem transformando os chamados 
atos de comércio, conceito de difícil entendimento, em atividade econômica, o que melhor se harmoniza com uma visão empresarial.

Admitindo-se com a doutrina moderna - que o Direito é um instrumento de controle social e talvez, o mais importante e o mais típico ${ }^{5}$. chega-se à concepção divulgada por Tércio Sampaio Ferraz Jr. de que: "O Direito está ligado a procedimentos institucionalizáveis por meio de normas, através das quais as institucionalizações se tornam socialmente viáveis. Finalmente, na dimensão de conteúdo, o Direito exerce sua função seletora, pois nem todos os programas, papéis, valores ou pessoas são juridicizados. $O$ Direito moderno tende a privilegiar programas de ação e papéis. Esta tendência, nas sociedades mais complexas, corresponde ao privilégio dado à sançāo como modo de tratamento das desilusões ao nivel temporal e ao procedimento como modo de institucionalizaçāo ao nivel social". ${ }^{6}$

A juridicização leva em conta, portanto, a expectativa normativa de setores sociais decorrentes em grande parte da especialização do trabalho, da divisão da economia por setores, e, é claro, tendo sempre presente o embasamento ideológico, visto este como uma espécie de tábua de valores vigentes, revelados pelas inclinações normativas. ${ }^{7}$

Em nosso tema, a adjetivação empresarial aposta ao nome, direciona a pesquisa para a identificação da "empresarialidade", nome, aqui, adotado para a designação do fenômeno em sua inteireza. Difícil não é constatar que no plano fenomenológico e certamente por suas implicações ideológicas, a empresa assumiu um papel de extraordinária importância na experiência social, tornando-se o epicentro do regime de produção, distribuição e circulação de bens e serviços voltados para o mercado de uma economia de massa, influindo no comportamento desse mesmo mercado, através da implantação de novas rotinas, novas técnicas negociais e novos procedimentos e ajustes organizacionais.

5. G. Lumia, Principios de teoria e ideologia del derecho, Madri, Debate, 1978, p. 15.

6. Cf. Função social da dogmática jurídica, São Paulo, RT, 1978, p. 115.

7. Este aspecto é, aliás, destacado pela doutrina, inclusive por Tércio Sampaio Ferraz Jr. que afirma: "Por exemplo, nas sociedades industriais, burocratizadas, há uma especialização em função de papéis e programas ideológicos mais do que pessoas e valores que continuam presentes, mas mediatizados pelos anteriores". Ibid., p. 116. 
Esse fenômeno assim importante gerou, como não podia deixar de ser, um forte grau de expectativas normativas, que ideologicamente haveriam de ser atendidas. Transpôs-se, destarte, para o plano legal os procedimentos empresariais, compreendendo as ações-tipo, decorrentes do exercício da atividade empresarial, além das normas de organização e atribuições correlatas. ${ }^{8}$

A variegada gama de interesses gravitando em torno da empresa (trabalhadores, Estado, credores, acionistas e sócios, as comunidades), desbordou até do âmbito estrito do Direito Comercial, alcançando outros ramos; não se estranhe assim o grande número de disposições legais fazendo menções à empresa, chegando mesmo várias delas, a defini-la. ${ }^{9}$ Tanto que a regulação normativa estatal da empresa fez a doutrina meditar sobre os instrumentos jurídicos de controle comportamental utilizados, levando à análise normativa por via do modelo empírico. ${ }^{10}$

Necessário assim e até indispensável para orientar o estudo é a compreensão do conteúdo, ou se se preferir do significado do termo empresa, ${ }^{11}$ que exerce papel influente como integrante do objeto das normas empresariais. Certamente, também não deve ficar excluída deste exercício, a eventual correspondência nominal à existência real do fenômeno, o que implica utilizar o termo empirismo, pelo seu outro significado, lembrando os dois sentidos que se lhe tem dado: 1. como captação da experiência real e 2. como afastamento da ciência nos conceitos.

No que concerne à experiência histórica tem-se a trajetória do Direito Comercial como especial ou excepcional em relação ao chamado Direito comum privado, e as implicações trazidas pelo aparecimento da empresa.

Nesse sentido insta examinar o histórico pelo prisma axiológico, fazendo um corte de constatação ideológica.

8. Essas normas todas, na maioria amplas e complexas, como, por exemplo, a Lei das Sociedades por Açōes, o Código da Propriedade Industrial, etc, já foram consideradas verdadeiros microssistemas jurídicos, assim como os procedimentos complexos, como mecanismo jurídico.

9. Cf. o rol dessas leis, em nosso livro A teoria jurídica ...ob. cit.

10. Cf. Tércio Sampaio Ferraz Jr., Teoria da norma jurídica: um modelo pragmático, na obra coletiva A norma jurídica, Sérgio Ferraz (coord.), Rio de Janeiro, Freitas Bastos, 1980.

11. Confundido ora com a firma, ora com a sociedade comercial, ora com o patrimônio, ora com o local onde a empresa exerce a sua atividade, e assim por diante. 
Vale relembrar mais uma vez, que, na Idade Média, o sistema econômico privilegiava a nobreza da terra, passando aos poucos também a privilegiar os comerciantes e artesãos reunidos nas corporações de oficio. Rompido o sistema feudal e o corporativo, verifica-se que mesmo com os Códigos, os proprietários da terra, produtores rurais, ficaram fora do sistema de ônus, obrigações e responsabilidades criado para os comerciantes, como, aliás, ocorre até hoje. Mas, os comerciantes não deixaram de ter alguns privilégios - ao menos em relação a outras profissões regulamentadas - como, por exemplo, as chamadas prerrogativas dos comerciantes (cf. arts. 21 a 25 do Código Comercial, e ainda hoje, no âmbito da propriedade comercial e da propriedade industrial). Com a evolução e a nascente influência da empresa, aumentaram esses privilégios; por exemplo, adota-se o benefício da concordata, estipulam-se exigências especiais para o exercício de certas atividades (como as instituições financeiras, seguradoras, tradings, etc.); impõe-se que certos tipos de contratos só sejam operados por empresas determinadas (como o leasing, por exemplo); dáse proteção à locação comercial e ao sistema da concorrência, além de inúmeras sanções premiais, como às exportadoras e outras.

Entretanto, sob a pressão dos fatos como o crescimento dos controles governamentais e as reivindicações sociais passa-se a aumentar a carga de obrigações e responsabilidades das empresas, destacando-se entre os inúmeros fatores dessas mudanças as pressões trabalhistas, as da comunidade e 0 aparecimento do consumidor. ${ }^{12} \mathrm{Em}$ conseqüência surgiram normas mais rígidas em relação às atividades das empresas; opta-se pela adoção do tipo de responsabilidade do empresário, agora pelo fato do produto; adotam-se normas de proteção ao consumidor; consagra-se a função social da empresa, reclamando-se aquela dos contratos, que aliás, se encontra prevista no Projeto do Código Civil; e redobra-se a fiscalização sobre as empresas, não só sobre operações como as instituições financeiras, seguradoras e outras como sobre os ajustes contratuais e organizacionais (abuso do poder econômico) e também em relação ao meio ambiente e outras. A propósito, é altamente revelador dessa

12. No Brasil, uma das poucas aberturas políticas, durante o período da repressão, tanto que o Governo tentou monopolizar o movimento através de vários projetos, como o do Ministério da Indústria e Comércio, o que não ocorreu, após a redemocratização do país, com a promulgação da Lei 8.078, de 11.09.1990, conhecida como Código de Defesa do Consumidor. 
tendência o exemplo da lei sobre os crimes econômicos, conhecidos como crimes do colarinho branco. E, finalmente, no âmbito político-ideológico, predicou-se a própria reforma da empresa, a participação efetiva dos trabalhadores na gestão $\mathrm{e}$ nos lucros das empresas, os comitês de fábricas e até a encampação e a socialização.

Nessa linha, é que se sustentou a idéia da empresa como instituição. Vale lembrar, que esta visão institucional da empresa vem sendo defendida por muitos, já há tempos, para vê-la como uma realidade ultrapassando a figura do empresário, que juntamente com os trabalhadores e outros, ficariam a ela sujeitos, aparecendo como uma organização acima dos interesses egoísticos, como sustentava há décadas Walter Rathenau. Sem dúvida que a conotação social desta colocação é transparente. Aqui, tomaremos o termo instituição ${ }^{13}$ com o significado que lhe atribui Miguel Reale, ou seja, como instituto correspondente a uma realidade viva social. Tomemos ainda a respeito, o conceito de instituto de Vicente Rao, como conjunto de normas coordenadas em direção a um fim comum e as relações que elas visam regular, o que Ihering chamava a ossatura do Direito, os corpos orgânicos jurídicos.

A esta altura, lembremo-nos da colocação de uma certa doutrina, como por exemplo, G. Lumia, da indagação de que se por baixo de uma relação jurídica existe uma relação preexistente, na vida real, que a norma visa regular, ou se é a própria norma que cria essa relação. A resposta não pode ser unívoca, já que a fenomenologia do Direito constata ambas as hipóteses. Às vezes, a norma jurídica reconhece e garante uma relação já preexistente, in rerum natura, como, por exemplo, a filiação que existe como fato natural; outras não, como a relação tributária criada pela norma. Ao se perguntar se a empresa existe como fenômeno real ou é o Direito que lhe dá existência, a resposta surge por dois aspectos: o Direito dá o reconhecimento jurídico da sua existência física representada pela organização dos fatores econômicos para a produção e distribuição de bens e serviços, voltando-se, é claro, no ajuste, às suas categorias, conceitos e construções, para a adoção de um regime destinado ao empresário, ao patrimônio empresarial e para o exercício dessa atividade empresarial.

13. Sem desprezar as concepçōes de Hauriou e Renard, e de Santi Romano. 
O fato é que pelo prisma fenomenológico, a empresa constitui uma unidade de produção congregando empresários e trabalhadores, por isso centro de convergência de inúmeros interesses. Como conjunto orgânico, modelo empírico com sentido normativo, das normas que o integram podem ser destacadas as práxis, rotinas, estatutos, operações, procedimentos, contratos e as leis que a regulam. Sob tal aspecto, verifica-se que também é uma instituição, pois constitui-se numa organização de pessoas, voluntária, fundada sobre uma relação de hierarquia e de cooperação entre os seus membros, com um objetivo comum, conforme a vê Santi Romano, ${ }^{14}$ e ainda insere-se no chamado pluralismo jurídico, posto que nem todas as suas normas são estatais.

Já as leis sobre a empresa decorrem do atendimento dos interesses congregados, respondendo às expectativas normativas: 1. para dar certeza e segurança às relações jurídicas derivadas do exercício da atividade empresarial; 2. para atender aos interesses dos trabalhadores, do Estado, em relação aos tributos e à produção econômica, dos consumidores e dos acionistas e sócios quando o empresário é uma sociedade comercial.

$\mathrm{Na}$ passagem do dado para o construído, verifica-se o reconhecimento da existência de normas através da captação do sentido normativo da experiência real, pois a atividade empresarial suscitou comportamentos passíveis de tipificação na sua reiteração temporal. Pode-se assim dizer que o legislador apreendeu essas normas e as sancionou sob a forma de leis, havendo, como é curial, as normas existentes que não foram ainda sancionadas e as que vão surgindo, como por exemplo, a série de contratos novos e de novos tipos de agregação empresarial.

Historicamente, o ciclo se completa: do marchans e do fabricans passa-se ao comerciante, sujeito correlato ao comércio em sentido amplo, abrangendo a indústria, transportes, bancos, bolsas, seguros, etc. e chega-se ao empresário, figura revelada integrando a noção de comerciante (cf. arts. 632-633 do Código Comercial francês e art. 19 do Regulamento 737, no Brasil). A empresa, por esse prisma, não era totalmente desconhecida, só que ficava subordinada no sistema, ao comerciante e ao ato de comércio (sendo

14. Lembremo-nos a propósito das imprecisões da teoria da instituição, da crítica de Savatier, de que "le mot institution est commode parce qu'elle est vague" 
comerciante quem exercia profissional e habitualmente atos de comércio). No exercício de qualificação apurava-se se a atividade praticada se enquadrava no rol dos atos de comércio (em sentido restrito ou mais amplamente dos atos auxiliares) e depois se eram praticados em caráter profissional e habitualmente. A empresa, pois, não entrava no ordenamento por si diretamente, tendo de passar por via da figura do comerciante; esse vezo, aliás, vai permanecer, mesmo na concepção do regime empresarial do Código Civil italiano de 1942, em que as empresas devem, antes de mais nada, serem consideradas comerciais, regime esse que o nosso Projeto do Código Civil, naquele inspirado, houve por bem corrigir, pois a empresa veio justamente para superar a noção de comerciante, que passa a ser um tipo de empresa (as empresas comerciais) e não as empresas um tipo de comerciante.

A recepção da empresa, no ordenamento jurídico, seja através de leis esparsas, ou de um Estatuto Geral do Empresário (como chamam os italianos a regulação jurídica da empresa, no Código Civil de 1942), acarretou então uma verdadeira superposição categorial, fenômeno que se assiste até hoje. É que surgiram novos institutos que requerem ser qualificados no plano jurídico, como, por exemplo, o da pessoa jurídica, o das sociedades unipessoais, o do estabelecimento comercial e seu correlato a universalidade de bens, o de atividade, o de empresário, o dos grupos econômicos, o de bens imateriais e assim por diante.

Abalam assim as estruturas formais de longa tradição, forçando o reconhecimento da sua existência e complicando a tarefa do jurista, pois resistem a se ajustar às categorias tradicionais.

Por esse aspecto, surge o problema da qualificação, ou seja, o ajuste do modelo na sua formulação econômica à tipificação estrutural a que alude Ascarelli. Nesse sentido, os esforços para enquadrar a empresa juridicamente - após ter sido negada essa viabilidade ${ }^{15}$ nas categorias básicas, sujeito, bens, e atos e fatos, esbarraram em inúmeras dificuldades. Entretanto, a aceitação da possibilidade da transposição do conceito econômico para o plano

15. Nesse sentido cf. Waldemar Ferreira que aliás comparava a empresa à Rebeca, personagem volátil, de que todos falavam e que nunca aparecia; também, Silvio Marcondes, e tantos outros; cf., a propósito, o nosso $A$ teoria jurídica... ob. cit. 
jurídico e a visão polifacética da empresa - perfis ${ }^{16}$ acabaram por ser da maior valia para o avanço que posteriormente se verificou.

Historicamente, pois, a regulação dos quatro perfis da empresa, pelo Código Civil italiano, trouxe contribuição de realce, pela reflexão crítica necessariamente imposta para a compreensão do instituto, dentro do sistema do ordenamento jurídico positivo, vale dizer, a visão operacional.

Procurou-se assim criar um modelo doutrinário que explicasse, completasse e justificasse o modelo normativo, surgindo, em conseqüência: 1. os que defendem a idéia de ter havido um quase perfeito ajuste do conceito jurídico à instituição econômica (como Franceschelli, por exemplo); 2. os que negam essa idéia, por várias razões, inclusive pela não consagração do possível unívoco conceito econômico. Vale ressaltar a propósito que a falta de unidade da visão conceitual leva a confusões, como por exemplo, os vários perfis de Asquini e a referência das leis cada qual com um sentido próprio, conforme entre nós, o fazem, a Consolidação das Leis do Trabalho, o Estatuto da Terra, a Lei contra os Abusos do Poder Econômico, as leis tributárias e as de ordem de intervenção econômica.

Procurando filtrar e superar essas dificuldades, foi que utilizamos a transposição do conceito econômico, caracterizado como organização dos fatores de produção, para o plano jurídico como atividade econômica organizada.

A visão final, portanto, pelo ângulo da atividade, aproveitando a brecha operada pelo corte polifacético, contribuiu decisivamente para dar nova configuração ao problema, completando a trilogia que permanecia oculta sob a simples dupla empresário-estabelecimento. O conceito jurídico baseado na atividade explica os seus correlatos, o sujeito (o empresário) e os bens (o estabelecimento).

Se o objeto da norma é representado por comportamentos, organização e competência, a norma empresarial surge como a norma cujo conteúdo são as relações decorrentes do exercício da atividade empresarial (pressupondo a "profissionalidade", a economicidade e a organização), sendo

16. Asquini apresenta quatro perfis; Ferrara Jr., três; Geraldo Vidigal acrescenta mais um perfil aos de Asquini, que eram: subjetivo, objetivo, operacional e institucional. 
certo também que as relações e o exercício da atividade empresarial implicam em normas de organização e de competências.

Por isso, a doutrina aponta como indispensável a adoção de um Estatuto Geral do Empresário, tendo como fundamentos básicos a importância social da empresa em nossos dias e suas repercussões no Direito. Tecnicamente, a substituição do antigo comerciante e da falha teoria dos atos de comércio, pelo atual de empresário e de atividade, é vantajosa, porque: a. propicia maior aderência à realidade; b. amplia a abrangência da matéria, alcançando outros modos do exercício das atividades, como a de serviços, por exemplo, e entre nós, superando a dicotomia civil ou comercial em várias atividades; c. propicia maior flexibilidade e "operacionalidade" na elaboração e interpretação das normas, como ocorre, por exemplo, no caso das sociedades por ações e em inúmeros outros institutos. Acarretaria, assim, uma verdadeira modernização das estruturas normativas voltadas para a realidade econômica.

Nesse sentido, Mario Ghidini ${ }^{17}$ justifica a existência de um Estatuto Geral do Empresário, assinalando que para melhor compreensão do sistema legal procede-se do óbvio conceito de que a empresa é um organismo produtivo, de fundamental importância social, que deve ser salvaguardada e protegida, enquanto:

1. constitui o único instrumento efetivo de produção de riqueza;

2. constitui o instrumento fundamental de ocupação e de distribuição da riqueza;

3. constitui um centro de propulsão do progresso, inclusive, cultural da sociedade.

O exercício da empresa compreende também interesses de terceiros, e assim:

a. dos trabalhadores dependentes;

b. dos clientes-consumidores (adquirentes de produtos, usuários dos serviços);

c. dos fornecedores e em geral do mercado de crédito;

d. dos empresários concorrentes.

17. Cf. Lineamenti del diritto dell'impresa, Milano, Giuffrè, 1978, p. 77 e ss. 
O surgimento e a evolução da empresa casa-se com a evolução do Direito Comercial, não só no sentido de adaptação às novas realidades sociais, como também no aprimoramento da sua "tecnicalidade" e da sua aproximação da própria ciência do Direito.

É consabido, tanto que ensinado reiteradamente nos manuais, que o Direito Comercial, surgiu espontaneamente no seio dos mercadores, como conjunto de regras de comportamento a serem observadas nas relações negociais do tipo mercantil. Anota-se ainda que perante o sistema jurídico então vigente na Europa, constituído de um amálgama de regras provindas do Direito Romano clássico, explicado através de glosas, de certos princípios nascentes no Direito Canônico e de regras dos costumes bárbaros, os mercadores nele não encontravam a rapidez, a flexibilidade e o informalismo necessários para reger condutas e pôr fim a conflitos. ${ }^{18}$ Por este último aspecto, a pluralidade de poderes, característica da Idade Medieval, implicava em igual variedade jurisdicional, utilizando-se no procedimento judiciário métodos pesados e demorados, o que não era de molde a atender às necessidades do comércio, que exigiam justiça rápida. Daí o surgimento nas corporações das decisões dos cônsules, pronunciadas sobretudo nas feiras, que, coletadas, deram origem ao chamado direito estatutário. Afirma-se, pois, que o Direito Comercial surgiu corrigendi vel supplendi gratia e portanto como ramo especial em relação ao Direito então vigente. Certamente por isso, que T. Ascarelli, adepto da visão histórico-cultural do Direito, que tende a considerá-lo, hoje, integrado ao Direito comum, permanecendo como categoria histórica, interpreta a evolução do Direito Comercial, nesses tempos, em termos que valem ser reproduzidos aqui: "Realmente", diz o mestre italiano, "se retrocedermos na história do Direito, fácil será constatar que o nascimento do Direito Comercial, se conjuga com uma fratura entre o direito romano-canônico comum então vigente e as exigências econômicas que hoje em dia denominaríamos capitalísticas, e que se fizeram sentir desde as comunas italianas no século XII, em contraposição ao sistema econômico entāo geralmente difundido. Estas exigências, assentes na liberdade de iniciativa e de concorrência num mercado livre, surgiram de início não quanto à indústria, mas

18. É altamente revelador dos costumes mercantis da época a fórmula utilizada nas feiras, para efetivar uma espécie de compensação entre os títulos de crédito. Cf. P. Huvelin, Essai historique sur le droit des marchés \& des foires, Paris, Rousseau, 1897. 
apenas quanto ao comércio, especialmente transmarino e bancário. Por isso se constituiu então em oposição ao direito comum, um direito especial que ainda hoje em dia, apesar de ter passado a abranger a atividade industrial, chamamos de comercial. Foi ele, no seu inicio, o direito da nascente burguesia das cidades; uma libertação dos vínculos da sociedade feudal e do direito romano-canônico entāo vigente" ${ }^{19}$

Recolhidas as regras consuetudinárias em livros de normas - as Compilações só mais tarde, a bem dizer no Renascentismo, serão alvos de mais detido exame, num esforço técnico-científico. Os primeiros tratados de Direito Comercial, já dotados de certa sistematização, surgem então: lembremo-nos de Benevenuto Stracca (1553); Segismundo Scaccia (1618); Raffaele de Turris (1641); Francesco Rocco (1655); Giovanni B. de Lucca (1669); Giuseppe M. Lorenzo de Casaregis (1707) e ainda o português Pedro de Santarém (1552). ${ }^{20}$

Os esforços de sistematização seguem melhor apoiados, na fase estatal, das Ordenações francesas, a terrestre de 1673 e a marítima de 1681, e finalmente com os Códigos Comerciais, tendo como exemplo o napoleônico de 1807.

Entretanto, apesar dessas transformações no campo legislativo, em que o Direito Comercial passou a ser Direito estatal, conquanto ainda ligado estreitamente à práxis, não se verifica um afinado ajuste à chamada Teoria Geral do Direito Civil, ramo que por ser considerado do direito comum, consagrava também seus estudos, na época, a temas que hoje estão a cargo da Teoria Geral do Direito.

Dessa falta de integração e de sistematização, o que Vivante chamaria de "debolezza" do Direito Comercial, queixavam-se os autores da época, como por exemplo, Jean Escarra. ${ }^{21}$ Da situação dava-se conta também Francesco Ferrara Filho:22 "Durante muito tempo foi abandonado o estudo do Direito Mercantil condenado como disse Vivante 'a viver na metade do caminho',

19. Cf. Panorama do direito comercial, Sảo Paulo, Saraiva, 1947, p. 22-3.

20. Cf. o meu Manual de direito comercial, $7^{\mathrm{a}}$ ed., São Paulo, Atlas, p. 28 e ss.

21. Cf. Principes de droit commercial, Paris, Sirey, 1934, p. 63 e ss.

22. Cf. Empresarios y sociedades, Revista de Derecho Privado, edição especial, p. 8 e ss, nota 4, Madrid, s.d.. 
entre o empirismo da prática e a severidade dos estudos do Direito Civil. Isto era facilitado pelo fato de se considerar o Direito Mercantil como um sistema independente de caráter excepcional em relação ao Direito Civil, e por isso os autores se limitavam, quando muito, a descrever suas instituiçōes, sem tratar de enquadrá-las nos princípios, ou se tentavam fazê-lo, tão logo tropeçavam em alguma dificuldade a atribuíam à peculiaridade do Direito Mercantil, terminando por dizer que se tratava de uma instituição sui generis. Iniciou-se uma nova fase com Vivante, o qual com o seu 'Tratatto di Diritto Commerciale', realizou a primeira sistematização científica desta matéria"

Veio assim o Direito Comercial observando uma postura própria, desvinculado da maior parte das preocupações da Teoria Geral do Direito, alardeando a sua condição ora de direito excepcional ora de direito especial, ${ }^{23}$ com as suas fontes normativas voltadas diretamente para a evolução dos fenômenos econômicos. Contudo, a partir de Vivante, como vimos, foi se encaminhando para um ajustamento que poderíamos denominar de técnicocientífico. Nos últimos tempos, é notório que os comercialistas vêm procurando se precatar dessa orientação a bem dizer empírica, voltando a sua atenção para os princípios e diretrizes da Teoria Geral do Direito.

Sem dúvida que a necessidade da integração do Direito Empresarial à Teoria Geral do Direito se acentuou com a reconhecida ruptura das novas formulações do Direito Empresarial com as categorias tradicionais e portanto com a busca de caminhos próprios, no âmbito da ciência do Direito.

No campo normativo atual, brasileiro, em que predomina o regime tripartido a que fizemos referência, pode-se traçar um quadro das principais normas referentes à atividade empresarial a elas destinadas diretamente ou que a elas fazem referência.

Assim, tem-se num campo mais geral, a antigamente chamada de matéria do comércio, como uma disciplina legal voltada para o comerciante (conceituado no art. 4 do Código Comercial) e para as relações jurídicas derivadas do exercício profissional da mercancia (que era confundida com a dos atos de comércio).

23. Sobre a questão do Direito Comercial como especial e excepcional cf. Alfredo Rocco, Princípios de direito comercial (parte geral), Sâo Paulo, Saraiva, 1931, p. 52 e ss. 
Em termos piramidais, pode-se começar pela Constituição Federal de 1988, que após ter cometido à União, privativamente, a competência para legislar sobre "Direito Comercial" (art. 22, I), dispõe no seu art. 5, XIII "é livre o exercício de qualquer trabalho, ofício ou profissão, observadas as condições de capacidade que a lei estabelecer" - complementado pelo inciso XXIX, que diz respeito à chamada propriedade industrial, que estatui: "a lei assegurará aos autores de inventos industriais privilégios temporários para sua utilização, bem como proteção às criações industriais, à propriedade das marcas, aos nomes de empresas $e$ a outros signos distintivos, tendo em vista o interesse social e o desenvolvimento tecnológico e econômico do País", e ainda os dispositivos do Título VII, sobre a Ordem Econômica e Financeira, especialmente do seu Capítulo I dedicado aos "Princípios Gerais da Atividade Econômica", como por exemplo, o seu art. 170 que se refere no caput à livre iniciativa e no inciso IV, à livre concorrência, e também ao seu parágrafo único que dispõe: "É assegurado a todos o livre exercício de qualquer atividade econômica, independentemente de autorização de órgão público, salvo nos casos previstos em lei". Faz ainda menção à empresa, no art. 171, e em relação à proteção à concorrência, estabelece no § 4o do art. 173, que: "A lei reprimirá o abuso do poder econômico que vise à dominação dos mercados, à eliminação da concorrência e ao aumento arbitrário dos lucros".

Certo é que através do Código Comercial de 1850 e das leis sucessivas que vieram sendo promulgadas, criou-se um regime jurídico de ônus, obrigaçōes, responsabilidades e proteção, para o comerciante.

Esse regime que, certamente, em termos normativos é de certa forma peculiar, como se vê pela análise das normas empresariais, de um lado protege o empresário, como por exemplo, na locação mercantil e no sistema de concorrência em consonância com o regime da propriedade industrial e das leis contra o abuso do poder econômico, e ainda, o do benefício da concordata.

Já em relação a ônus, verifica-se que são constituídos por certas formalidades que os comerciantes podem ou não cumprir, como, por exemplo, a sua inscrição no Registro de Comércio (sem o que permanece na situação, conhecida entre nós, de comerciante de fato), com certas sanções diretas ou indiretas pelo não-cumprimento, como, por exemplo, o não-reconhecimento da 
qualidade de comerciante para certos fins, como o da concessão da concordata, por exemplo.

No que tange às obrigações (cf. arts. 10 e ss. do Código Comercial), estas também conhecidas por atos e formalidades a cargo do comerciante, podese apontar, a mantença de livros contábeis e da escrituração correta e em dia, cuja sanção, por exemplo, em caso de falência, será a de considerá-la fraudulenta, sujeitos seus responsáveis aos crimes falimentares conseqüentes.

Em termos da responsabilidade, os empresários podem ser alvos da imputabilidade, nos mais variados casos previstos pelas leis também as mais diversas, desde as que protegem o meio ambiente até as de proteção ao crédito público, como por exemplo, no caso de falência.

Paralelamente a esse regime jurídico-legal de regulação do comerciante, cujo conceito vem deduzido no art. 4o do Código Comercial, é que se verifica a existência da empresa, reconhecida e conceituada ou ao menos referida em inúmeras leis, pressionando o velho sistema ditado para o antigo comerciante, tendo como pano de fundo o modelo doutrinário, de inspiração moderna, cujo texto expressivo, é o Projeto do Código Civil, que, como já mencionamos, dita toda uma disciplina jurídica para a "empresarialidade", sob um título denominado justamente de Direito da Empresa.

O quadro normativo empresarial hoje, no Brasil, é incomensurável: e nele se constatam claramente leis de vârias naturezas que ora se ajuntam ao sistema normativo tradicional, principalmente o representado pela parte geral do Código Civil, ora dele se afastam por apresentarem características peculiares ditadas pela atividade empresarial.

Assim é que se podem apontar normas qualificadoras, como as que definem as empresas e o próprio comerciante, esta encontrada no art. $4^{\circ}$ do Código Comercial, e aquelas nas várias leis que já citamos.

Por outro lado encontram-se as reguladoras disciplinando as açõestipo da atividade e da organização empresarial, estas verdadeiros microssistemas jurídicos quase autônomos, tais o número de artigos e a tendência a uma regulamentação completa e pormenorizada.

Em relação ao ordenamento vigente, elas se colocam ora como excepcionais quando cuidam de maneira diversa matéria que já é cuidada pelo Direito Civil; ora como especiais e são a maioria, pois cuidam de matéria 
específica, como por exemplo: o Código da Propriedade Industrial, a Lei de Falências, a Lei das Sociedades, tanto por quotas como por ações.

E ainda as chamadas de comuns que tratam de matéria envolvendo atos e negócios não-exclusivos dos comerciantes, como, por exemplo, a Lei do Cheque, instituto hoje utilizado por todos.

Estas leis em geral regulam verdadeiros mecanismos jurídicos, assim chamados pois são negócios complexos, como, por exemplo, as operações de fusão, incorporação, cisão, os contratos de representação comercial autônoma, os dos concessionários, os de leasing, os de factoring, e assim por diante.

Nesse sentido é que se constata que foram deitadas abaixo várias idéias cristalizadas que se apresentaram sempre como verdadeiros mitos: assim, por exemplo, a desconsideração da pessoa jurídica; a admissão da sociedade unipessoal (o que levaria Champeau a duvidar de que o contrato societário ainda exista); a separação da propriedade e do controle, na riqueza em geral, e especificamente nas sociedades por ações, com a regulação do controlador e suas responsabilidades; e por derradeiro, através do Código de Defesa do Consumidor, a consagração da responsabilidade pelo fato de produto, a inversão do ônus da prova, e tantas outras.

Toda essa grandeza normativa ao mesmo tempo em que enriquece o Direito Empresarial de nossos dias, também põe em causa a sua real eficácia, como um verdadeiro teste, contínuo e infindável.

Testes também:

1. extensivo ao próprio Direito, entendido como instrumento do controle social;

2. para avaliar a dimensão e a intensidade dos choques de interesses que tornam a sociedade cada vez mais conflituosa;

3. para as teorias sociais, sobretudo para aquelas ideologias que advogam a reforma da empresa, a sua função social e a integração com a sociedade.

O presente e o futuro nos darão os resultados desses desafios, sem esquecer que a Economia se torna cada vez mais política e opressora dos direitos dos cidadãos e da livre marcha das empresas, tendo, como é evidente, transformado o país numa espécie de nação-cobaia. 
O que leva a lembrar a visão profética do poeta maior Fernando Pessoa ao esculpir estes versos inesquecíveis:

" $E$ mais do que isto

É Jesus Cristo

Que não sabia nada de finanças

Nem consta que tivesse biblioteca

.............". 